\title{
Puma Is a Dominant Regulator of Oxidative Stress Induced Bax Activation and Neuronal Apoptosis
}

\author{
Diana Steckley, ${ }^{1 \star}$ Meera Karajgikar, ${ }^{1 *}$ Lianne B. Dale, ${ }^{1}$ Ben Fuerth, ${ }^{1}$ Patrick Swan, ${ }^{1}$ Chris Drummond-Main, ${ }^{1}$ \\ Michael 0. Poulter, ${ }^{1}$ Stephen S. G. Ferguson, ${ }^{1}$ Andreas Strasser, ${ }^{2}$ and Sean P. Cregan ${ }^{1}$ \\ ${ }^{1}$ Robarts Research Institute and the Department of Physiology and Pharmacology, University of Western Ontario, London, Ontario, Canada N6A 5K8, and \\ ${ }^{2}$ The Walter and Eliza Hall Institute of Medical Research, Parkville 3050, Victoria, Australia
}

Oxidative stress has been implicated as a key trigger of neuronal apoptosis in stroke and neurodegenerative conditions such as Alzheimer's disease, Parkinson's disease and amyotrophic lateral sclerosis. The Bcl-2 homology 3 (BH3)-only subfamily of Bcl-2 genes consists of multiple members that can be activated in a cell-type- and stimulus-specific manner to promote cell death. In the present study, we demonstrate that, in cortical neurons, oxidative stress induces the expression of the BH3-only members Bim, Noxa, and Puma. Importantly, we have determined that Puma-/- neurons, but not Bim-/- or Noxa-/- neurons, are remarkably resistant to the induction of apoptosis by multiple oxidative stressors. Furthermore, we have determined that Bcl-2-associated X protein (Bax) is also required for oxidative stress induced cell death and that Puma plays a dominant role in regulating Bax activation. Specifically, we have established that the induction of Puma, but not Bim or Noxa, is necessary and sufficient to induce a conformational change in Bax to its active state, its translocation to the mitochondria and mitochondrial membrane permeabilization. Finally, we demonstrate that whereas both Puma and $\mathrm{Bim}_{\mathrm{EL}}$ can bind to the antiapoptotic family member Bcl- $\mathrm{X}_{\mathrm{L}}$, only Puma was found to associate with Bax. This suggests that in addition to neutralizing antiapoptotic members, Puma may play a dominant role by complexing with Bax and directly promoting its activation. Overall, we have identified Puma as a dominant regulator of oxidative stress induced Bax activation and neuronal apoptosis, and suggest that Puma may be an effective therapeutic target for the treatment of a number of neurodegenerative conditions.

Key words: apoptosis; Bcl-2; BH3 proteins; oxidative stress; neurodegeneration; cell death

\section{Introduction}

There is substantial evidence indicating that a significant portion of affected neurons in acute and chronic neurodegenerative conditions die through a process known as apoptosis (Vila and Przedborski, 2003; Chan, 2004). Apoptosis is a genetically programmed cell death pathway that typically involves caspase activation and distinct morphological changes in the cell. Neurons exhibiting apoptotic features have been observed in postmortem tissue of individuals affected by stroke and from patients diagnosed with Alzheimer's disease, Parkinson's disease, and amyotrophic lateral sclerosis (ALS) (Tatton et al., 1998; Martin, 1999; Gastard et al., 2003; Chan, 2004). Furthermore, a number of studies have demonstrated that molecular and pharmacological inhibitors of caspases can reduce or delay neuronal cell death in animal models of cerebral ischemia and neurodegenerative disease (Li, 2000; Le et al., 2002). However, caspase activation occurs at a relatively late step in the cell death process and specific

\footnotetext{
Received July 26, 2007; revised Sept. 20, 2007; accepted 0ct. 8, 2007.

This work was supported by The Heart and Stroke Foundation Grant NA 5758, the Canadian Institutes of Health Research Grant MOP68995, and the Krembil Foundation. The authors are grateful to Gillian Bayley and Meggan Brine for their technical assistance in certain aspects of these studies, and to Profs. J. Adams and S. Cory for generously providing the Bim, Noxa, and Puma heterozygous mouse lines.

*D.S. and M.K. contributed equally to this work.

Correspondence should be addressed to Dr. Sean P. Cregan, Robarts Research Institute, 100 Perth Drive, London, Ontario, Canada, N6A 5K8. E-mail: scregan@robarts.ca.

DOI:10.1523/JNEUROSCI.3400-07.2007

Copyright $\odot 2007$ Society for Neuroscience 0270-6474/07/2712989-11\$15.00/0
}

inhibition of these proteases is typically not sufficient to prevent neuronal cell death (Miller et al., 1997; Johnson et al., 1999). This is likely because of compromised mitochondrial function and the activation of caspase-independent death effectors (Cregan et al., 2004b). Therefore, to effectively prevent neuronal cell death and retain neurological function it will be critical to identify the molecular pathways that regulate apoptotic events upstream of mitochondrial dysfunction.

The Bcl-2 protein family consists of proapoptotic and antiapoptotic members that interact at both the physical and functional level to regulate mitochondrial integrity and apoptotic cell death (Tsujimoto, 2003). After activation, proapoptotic family members such as Bcl-2-associated $\mathrm{X}$ protein (Bax) and $\mathrm{Bcl}-2$ homologous antagonist killer (Bak) target the mitochondria and cause membrane permeabilization and the release of proapoptotic effectors, including cytochrome-c and apoptosis-inducing factor (Kluck et al., 1997; Cregan et al., 2002). When released into the cytoplasm cytochrome-c facilitates activation of the apoptotic activating factor-1 (Apaf-1)/Caspase-9 apoptosomal complex that triggers the caspase cascade and subsequent cell degradation (Li, 1997). Bax/Bak activation in response to apoptotic stimuli can be regulated by the actions of a third class of Bcl-2 family members known as the Bcl-2 homology 3 (BH3)-domain-only proteins. $\mathrm{BH} 3$-only proteins are thought to promote apoptosis by binding to prosurvival Bcl-2 family members, thereby unleashing $\mathrm{Bax} / \mathrm{Bak}$. The BH3-only protein family consists of eight known 
members that can be activated through a variety of transcriptional and post-translational mechanisms depending on the cell type and death stimulus involved (Puthalakath and Strasser, 2002). Therefore, it is believed that the different BH3-only proteins provide a link between the diverse upstream signaling pathways and the convergent downstream effectors in apoptotic cell death.

Oxidative stress has been implicated as a key trigger of neuronal cell death in stroke and several chronic neurodegenerative disorders including Alzheimer's disease, Parkinson's disease, and ALS (Jenner, 1998; Simpson et al., 2003; Sugawara and Chan, 2003; Tieu et al., 2003; Aslan and Ozben, 2004; Andersen, 2004). Therefore, identifying the molecular regulators of oxidative stress induced neuronal apoptosis will be an important step in the development of therapeutic strategies to treat these neurodegenerative conditions. In this study we identify the critical Bcl-2 family members involved in the regulation of oxidative stress induced neuronal apoptosis.

\section{Materials and Methods}

Animals. Apaf-1, Bax, and p53 mice (The Jackson Laboratory, Bar Harbor, ME) were maintained on a C57BL/6 background and genotyped as described previously (Cregan et al., 1999; Fortin et al., 2001). Mice carrying targeted null mutations for Bim, Noxa, and Puma were generated on a C57BL/6 background in the laboratory of Dr. Andreas Strasser (WEHI, Victoria, Australia) and the genotyping of these mice was performed as described previously (Bouillet et al., 1999; Villunger et al., 2003).

Neuronal cell cultures. Cortical neurons were dissociated from E14.5E15.5 mice and cultured in Neurobasal medium containing B27 and N2 supplements (Invitrogen, Eugene, OR) as described previously (Fortin et al. 2001). Drug treatments were initiated after $4 \mathrm{~d}$ in culture. For treatments with hydrogen peroxide (Sigma, St. Louis, MO) and tert-butyl hydroperoxide (Sigma), neurons were exposed to drugs in HBSS for 60 or 90 min respectively, and then returned to their conditioned medium. In the indicated studies RNA or protein synthesis inhibitors actinomycin-D (ActD) and cycloheximide (CHX) (Sigma) were added to cultures after return to conditioned media. For NOC-12 (Calbiochem, La Jolla, CA) or 1-methyl-4-phenylpyridinium iodide (MPP+; Sigma) treatments, drugs were added directly to the culture medium and were not washed out. Preparation, titration, and transduction of neurons with recombinant adenoviral vectors expressing HA-PUMA or green fluorescent protein (GFP) were performed as previously described (Cregan et al., 2004a).

Cell death and survival assays. Neuronal apoptosis was assessed by examining nuclear morphology in Hoechst 33258 stained cells. Neurons were fixed in 4\% paraformaldehyde and stained with Hoechst 33258 (1 $\mu \mathrm{g} / \mathrm{ml}$ ) and the fraction of cells exhibiting an apoptotic nuclear morphology (chromatin condensation and/or apoptotic bodies) was determined. Neuronal survival was also determined by Live/Dead viability assay (Invitrogen) as described previously (Fortin et al., 2001). Briefly, cells were stained with Calcein-AM $(2 \mu \mathrm{M})$ and ethidium homodimer $(2 \mu \mathrm{M})$ for 15 min and the fraction of live (Calcein-AM positive) and dead (ethidium positive) cells was determined. In both assays, neurons were visualized by fluorescence microscopy (IX70; Olympus, Tokyo, Japan) and images were captured with a CCD camera (Q-imaging, Burnaby, British Columbia, Canada) and Northern Eclipse software (Empix Imaging, Mississauga, Ontario, Canada). Images were captured and scored by a blinded observer and a minimum of 400 cells were analyzed per well.

Caspase activity assay. Neurons were harvested in caspase lysis buffer ( $1 \mathrm{~mm} \mathrm{KCl,} 10$ mм HEPES, pH 7.4, $1.5 \mathrm{~mm} \mathrm{MgCl}_{2}, 1 \mathrm{~mm}$ DTT, $1 \mathrm{~mm}$ PMSF, $5 \mu \mathrm{g} / \mathrm{ml}$ leupeptin, $2 \mu \mathrm{g} / \mathrm{ml}$ aprotinin, and $10 \%$ glycerol) and 10 $\mu \mathrm{g}$ of protein was used in caspase activity assay as described previously (Cregan et al., 1999). Briefly, protein samples were added to caspase reaction buffer [25 mм HEPES, pH 7.4, 10 mm DTT, 10\% sucrose, $0.1 \%$ 3-[(3-cholamidopropyl)dimethylammonio]-1-propanesulfonate (CHAPS), and $10 \mu \mathrm{M} \mathrm{N}$-acetyl-Asp-Glu-Val-Asp-(7-amino-4trifluoromethyl coumarin) (Ac-DEVD-AFC)] and fluorescence pro- duced by DEVD-AFC cleavage was measured on a SpectraMax M5 fluorimeter (excitation $400 \mathrm{~nm}$, emission $505 \mathrm{~nm}$ ) over a $1 \mathrm{~h}$ interval. Caspase-3-like activity is reported as the ratio of the fluorescence output in treated samples relative to corresponding untreated controls.

Quantitative RT-PCR. RNA was isolated using Trizol reagent as per manufacture's instructions (Invitrogen) and 20 ng of RNA was used in one-step Sybr green reverse transcription (RT)-PCR (QuantiTect; Qiagen, Hilden, Germany). RT-PCR was carried out on a Chromo4 system (MJ Research, Watertown, MA; Bio-Rad, Hercules, CA) and changes in gene expression were determined by the $\Delta\left(\Delta C_{t}\right)$ method using S12 transcript for normalization. Data is reported as fold increase in mRNA levels in treated samples relative to corresponding untreated control cells for each transcript. All PCRs exhibited high amplification efficiency $(>90 \%)$ and the specificity of PCR products was confirmed by sequencing. Primer sequences used for gene specific amplification are available on request.

Cytochrome-c and MAP-2 immunostaining. Neurons were fixed in $4 \%$ paraformaldehyde, washed in three changes of PBS and then incubated for $2 \mathrm{~h}$ with monoclonal antibodies directed against cytochrome-c (BD PharMingen, San Diego, CA) or microtubule-associated protein-2 (MAP-2; Roche, Welwyn Garden City, UK) as described previously (Cregan et al., 2002). Cells were then washed and incubated for $45 \mathrm{~min}$ with Alexa-488 conjugated goat anti-mouse IgG secondary antibody (Invitrogen) and counterstained with Hoechst $33258(1 \mu \mathrm{g} / \mathrm{ml})$. To evaluate mitochondrial membrane permeabilization cells were visualized by fluorescence microscopy and cells exhibiting punctate, cytoplasmic cytochrome-c staining were considered to have maintained membrane integrity. Images were captured and scored by a blinded observer and a minimum of 300 cells were analyzed per well.

Western blot analysis. To prepare whole-cell lysates, neurons were incubated in lysis buffer ( $10 \mathrm{~mm}$ HEPES, $150 \mathrm{~mm} \mathrm{NaCl}, 0.5 \mathrm{~mm}$ EDTA, 0.5\% CHAPS, $0.5 \mathrm{~mm}$ PMSF, $5 \mu \mathrm{g} / \mathrm{ml}$ aprotinin, $5 \mu \mathrm{g} / \mathrm{ml}$ leupeptin) for $30 \mathrm{~min}$ on ice and soluble extract was recovered by centrifugation. For subcellular fractionation neurons were harvested in isotonic buffer (10 mM HEPES, $210 \mathrm{~mm}$ mannitol, $70 \mathrm{~mm}$ sucrose, $0.5 \mathrm{~mm}$ EDTA, and protease inhibitor mixture) and lysed by 20 passes through a 25 -gauge syringe. Unbroken cells and nuclei were cleared by 5 min centrifugation at $750 \mathrm{~g}$ and the supernatant was then centrifuged for $20 \mathrm{~min}$ at $10,000 \times g$ to separate the cytosol and heavy membrane (HM) fractions. The HM fractions were incubated for 20 min in $0.1 \mathrm{M} \mathrm{Na}_{2} \mathrm{CO}_{3}$ and then extracted with standard lysis buffer. Protein concentration was determined by BCA assay (Pierce, Rockford, IL) and $40 \mu \mathrm{g}$ of protein was separated on $12.5 \%$ SDS-PAGE gels and then transferred to nitrocellulose membrane. Membranes were blocked for $2 \mathrm{~h}$ in TBST ( $10 \mathrm{~mm}$ Tris, $150 \mathrm{~mm} \mathrm{NaCl}, 0.1 \%$ Tween 20) containing 5\% skim milk and then incubated overnight with primary antibodies to Bax, Actin (Santa Cruz), BIM (Stressgen), PUMA or cytochrome c oxidase subunit IV (COX-IV) (both from Cell Signaling Technology, Beverly, MA) in TBST containing 3\% skim milk. Membranes were then washed in TBST and then incubated for $1 \mathrm{~h}$ with appropriate HRP-conjugated goat anti-rabbit IgG secondary antibodies. Membranes were again washed and then developed by an enhanced chemiluminescence system according to manufacturer's instructions (Amersham Biosciences, Arlington Heights, IL).

Immunoprecipitation assay. Neuronal lysates were prepared in lysis buffer (10 mм HEPES pH 7.4, $150 \mathrm{~mm} \mathrm{NaCl}$ ) containing 1\% CHAPS and protease inhibitors. For immunoprecipitation, $250 \mu \mathrm{g}$ of cell lysate was incubated with the conformation specific anti-Bax mouse monoclonal antibody $6 \mathrm{~A} 7$ (BD PharMingen) and protein G-Sepharose beads for $4 \mathrm{~h}$ at $4^{\circ} \mathrm{C}$. Precipitated complexes were released by boiling in SDS sample buffer and subjected to Western blot analysis as described above using anti-Bax rabbit polyclonal antibody (Santa Cruz Biotechnology, Santa Cruz, CA).

GST pulldown assays. PUMA and $\mathrm{BIM}_{\mathrm{EL}} \mathrm{cDNAs}$ were inserted into pGEX4T1 plasmid (Amersham) to generate a glutathione $S$-transferase (GST)-PUMA and GST-BIM $\mathrm{EL}_{\mathrm{E}}$ fusion proteins. Expression of GSTfusion proteins was induced in DH5 $\alpha$ bacterial cells with $1 \mathrm{~mm}$ isopropyl $\beta$-D-1-thiogalactopyranoisde and GST-PUMA/BIM proteins were purified from cell lysates on glutathione-agarose columns. Neurons were harvested and extracted for $1 \mathrm{~h}$ in ice-cold lysis buffer and lysates $(500 \mu \mathrm{g}$ 
A
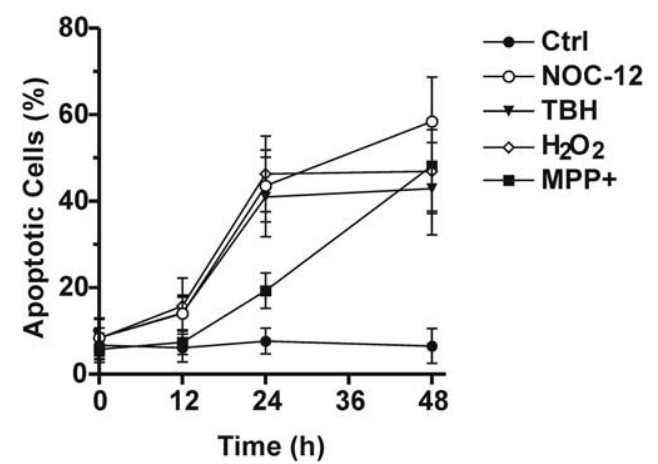

B

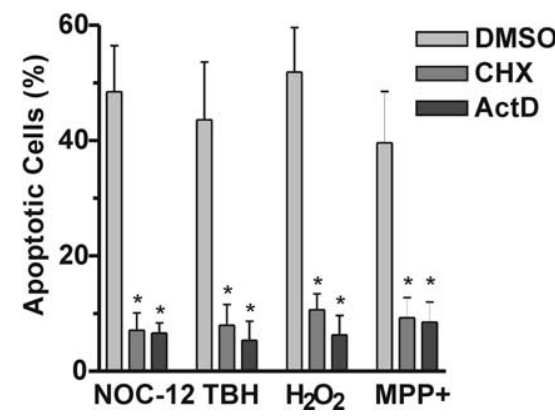

C

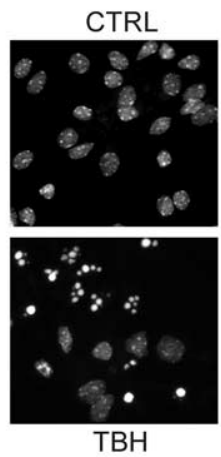

Figure 1. Oxidative damage triggers neuronal apoptosis through a mitochondrial pathway. $\boldsymbol{A}$, Cortical neurons were treated with NOC-12 $(200 \mu \mathrm{M})$, TBH $(200 \mu \mathrm{M}), \mathrm{H}_{2} \mathrm{O}_{2}(20 \mu \mathrm{M})$, or MPP $+(100 \mu \mathrm{M})$ and the fraction of apoptotic cells was determined by Hoechst 33258 staining at the indicated times $(n \geq 4)$. Representative images of Hoechst 33258 stained neurons captured $48 \mathrm{~h}$ after indicated treatments are shown. $B$, Cortical neurons were treated with the oxidative stressors as above in the presence of $\mathrm{CHX}$ (5 $\mu \mathrm{g} / \mathrm{ml})$, ActD (5 $\mu \mathrm{g} / \mathrm{ml})$, or DMSO (solvent control) and the fraction of apoptotic cells was determined by Hoechst 33258 staining at $40 \mathrm{~h}\left(n=4 ;{ }^{*} p<0.001\right)$. C, Cortical neurons derived from wt and Apaf- $1^{-1-}$ littermates were treated with the indicated oxidative stressors as above and assayed for caspase-3-like activity at $24 \mathrm{~h}$ (or $40 \mathrm{~h}$ in the case of MPP + treatment) ( $n \geq$ $\left.3 ;{ }^{*} p<0.001\right)$.

of protein) were incubated with GST-PUMA, GST-BIM, or unfused GST $(50 \mu \mathrm{g})$ for $1 \mathrm{~h}$ at $37^{\circ} \mathrm{C}$. Equilibrated GST-Sepharose beads were added and after $2 \mathrm{~h}$ incubation complexes were recovered by centrifugation. The beads were washed twice in lysis buffer and then interacting proteins were eluted in $50 \mathrm{~mm}$ Tris- $\mathrm{HCl}, \mathrm{pH} 8.0$ containing $10 \mathrm{~mm}$ reduced glutathione. Aliquots were then separated by SDS-PAGE and immunoblotted for Bcl- $\mathrm{x}_{\mathrm{L}}$ or Bax as described above.

Electrophysiology. Electrophysiology measurements were performed on neurons after $10 \mathrm{~d}$ in culture. Culture dishes were placed in an Olympus IX-70 inverted microscope and neurons were continuously perfused in Ringer's solution consisting of (in mM) $145 \mathrm{NaCl}, 5$ $\mathrm{KCl}, 10 \mathrm{HEPES}, 2 \mathrm{CaCl}_{2}, 2 \mathrm{MgCl}_{2}$, and 10 glucose $(300-310 \mathrm{mOsm}$, $\mathrm{pH}$ adjusted to 7.3 ). Patch-clamp recordings from individual cells were made using electrodes made from Sutter Instruments borosilicate glass (outer diameter, $1.5 \mathrm{~mm}$; inner diameter, $0.86 \mathrm{~mm}$ ) in electrode solution composed of (in mM) $145 \mathrm{KCl}, 10 \mathrm{NaCl}, 10 \mathrm{HEPES}$, $1 \mathrm{Na}_{2}$ EDTA, and 20 glucose (adjusted to 300-320 mOsm with sucrose, pH 7.3, free $\mathrm{Ca}^{2+}$ was $80 \mathrm{~nm}$ ). A Molecular Devices Axopatch 200B amplifier was used to record voltage-current relationships and the spontaneous synaptic currents ( $5 \mathrm{kHz}$ low pass filtered) were digitized $(10 \mathrm{kHz})$ using a Molecular Devices Digidata $1200 \mathrm{~A}$ interface. All recordings were performed at room temperature $\left(20-22^{\circ} \mathrm{C}\right)$ on visually identified pyramidal neurons. Neurons were clamped at a membrane potential of $-60 \mathrm{mV}$ and electrode resistance ranged from 3 to $6 \mathrm{M} \Omega$. Series resistance was typically in the range of 7-15 M $\Omega \mathrm{s}$ with compensation up to $80 \%$. Sodium current density was estimated from measuring the peak of the sodium current in $V-I$ mode and then normalizing this value based on an estimate of the cell size from the

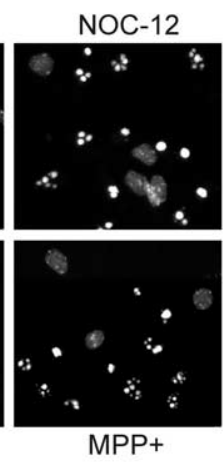

total cellular capacitance. For an estimate of the synaptic activity present the frequency of spontaneous synaptic currents was estimated from 20 min long recordings where the events were counted by the operator off line and is expressed in events per second (hertz).

Data analysis. Data is reported as mean and SD. The value $n$ represents the number of independent neuron cultures or number of embryos of indicated genotype from which independent neuron cultures were prepared. Differences between groups were determined by one-way ANOVA followed by post hoc Tukey test and were considered statistically significant when $p<0.05$.

\section{Results}

Oxidative damage triggers neuronal apoptosis through a mitochondrial pathway

To characterize oxidative stress induced neuronal apoptosis we treated cortical neurons with agents known to generate hydroxyl- $\left(\mathrm{H}_{2} \mathrm{O}_{2}\right)$, peroxyl- (t-butyl hydroperoxide), or nitric oxide- (NOC-12) free radicals, all of which have been implicated in neurodegenerative conditions (Andersen, 2004; Margaill et al., 2005). We also treated neurons with MPP + the active metabolite of the drug 1-methyl-4phenyl-1,2,3,6-tetrahydropyridine

(MPTP) that is known to cause Parkinson's syndrome in rodents and humans (Przedborski and Ischiropoulos, 2005). $\mathrm{MPP}+$ is an inhibitor of the respiratory chain complex-I and its toxicity has been shown to be caused by the consequent production of oxygen derived free radicals (Fallon et al., 1997; Przedborski and Ischiropoulos, 2005; Richardson et al., 2007). All of these oxidative stressors triggered a significant increase in the fraction of cells exhibiting an apoptotic nuclear morphology characterized by chromatin condensation and/or nuclear fragmentation (Fig. $1 A$ ). After treatment with $\mathrm{H}_{2} \mathrm{O}_{2}$, tertbutyl hydroperoxide (TBH), and NOC-12 the fraction of apoptotic neurons began to increase after $\sim 12 \mathrm{~h}$ and continued to rise for at least $24 \mathrm{~h}$ (Fig. 1A). Cell death in response to MPP + treatment was notably slower as the fraction of apoptotic cells only began to increase after $\sim 24 \mathrm{~h}$ and continued to rise over the next $48 \mathrm{~h}$. To determine whether oxidative stress induced apoptosis is dependent on gene induction, we examined the effect of the transcription and translation inhibitors actinomycin-D and cycloheximide. As shown in Figure $1 B$, both of these inhibitors essentially blocked oxidative stress induced neuronal cell death suggesting that de novo gene expression is required for activation of the apoptotic program.

Apaf-1 is known to be a key regulator of caspase activation in mitochondrial driven apoptotic pathways (Yoshida et al., 1998). To determine whether oxidative stress induces caspase activation through the mitochondrial pathway we treated neurons derived from Apaf-1 $1^{-/-}$mice and wild-type (wt) control littermates with NOC-12, $\mathrm{H}_{2} \mathrm{O}_{2}, \mathrm{TBH}$, and MPP + . All of these oxidative stressors triggered a significant induction of caspase-3-like activity in wt control neurons ( $>10$-fold), but not in Apaf-1 $1^{-/-}$neurons, consistent with the involvement of the intrinsic (mitochondrial) apoptotic pathway (Fig. 1C). 
Oxidative stress induces the expression of the BH3-only members Bim, Noxa, and Puma

Bcl-2 family proteins can be activated in a cell type and stimulus specific manner and are known to be key regulators of mitochondrial apoptotic pathways. Because de novo gene expression appeared to be required for activation of cell death (Fig. $1 B$ ), we examined the expression profiles of various proapoptotic Bcl-2 family members by quantitative RT-PCR. As shown in Figure 2A, treatment with $\mathrm{H}_{2} \mathrm{O}_{2}$ or TBH led to a significant increase in the expression of the $\mathrm{BH} 3$ only genes Noxa and Puma beginning $\sim 5 \mathrm{~h}$ and peaking at $\sim 10 \mathrm{~h}$ after drug exposure. However, these treatments did not affect the expression of other $\mathrm{BH} 3$-only family members including Bim, Bid, and Bad or the multi-BH domain proapoptotic Bax. Interestingly, NOC-12 and MPP + treatment led to a different pattern of $\mathrm{BH} 3$-only gene induction. Specifically, Puma and Bim gene expression was upregulated, whereas the expression of Noxa and other $\mathrm{BH} 3$-only members was not. It was noted that the induction of Puma and Bim after MPP + treatment was slower and only became evident after $\sim 20 \mathrm{~h}$, consistent with the delayed onset of apoptosis observed in this death paradigm (Fig. 1A). We also noted that the increase in Puma, Bim and Noxa mRNA levels was essentially blocked in the presence of actinomycin-D consistent with enhanced transcription of these $\mathrm{BH} 3$-only genes (Fig. 2B).

As illustrated in Figure 2C, oxidative stress also triggered an increase in Puma and Bim protein levels specifically within the mitochondrial-enriched HM fraction. Similar to the mRNA profiles, Puma protein levels were increased in response to all oxidative stressors whereas Bim protein was upregulated predominantly in response to NOC-12 and $\mathrm{MPP}+$ treatments. The Bim antibody used in these studies can detect all three Bim isoforms $\left(\mathrm{Bim}_{\mathrm{EL}}, \mathrm{Bim}_{\mathrm{L}}\right.$, and $\left.\mathrm{Bim}_{\mathrm{S}}\right)$, however, similar to other cell death paradigms (Bouillet et al., 1999; Putcha et al., 2001; Whitfield et al., 2001), oxidative damage appeared to preferentially induce the expression of $\mathrm{Bim}_{\mathrm{EL}}$. Although Noxa mRNA levels were increased in response to $\mathrm{H}_{2} \mathrm{O}_{2}$ and $\mathrm{TBH}$ treatments, we were unable to detect Noxa protein using several different commercially available antibodies. However, we believe that this is an antibody issue because ectopically expressed Flag-Noxa could be detected with antibodies directed against the Flag-epitope, but not with any of the Noxa antibodies tested (data not shown).
A
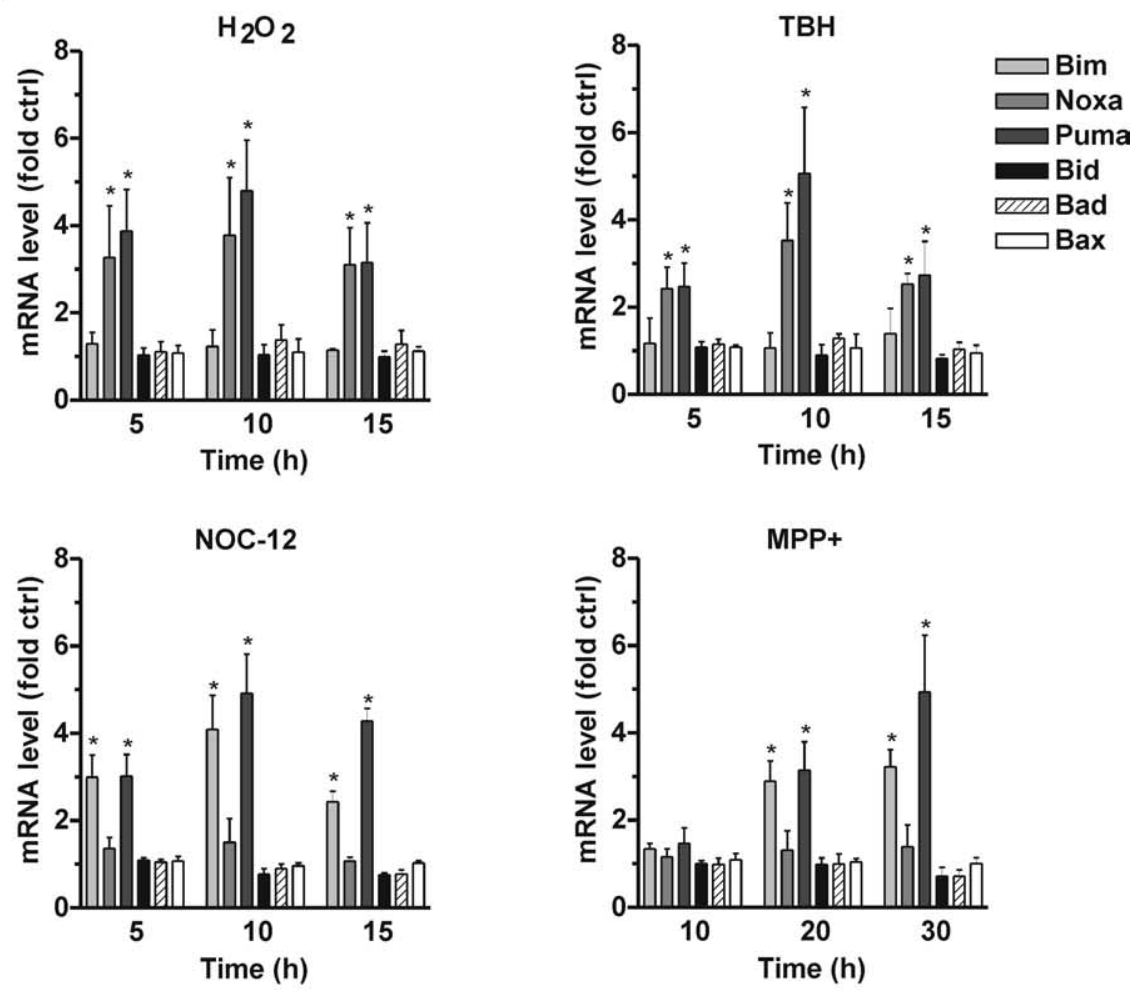

B
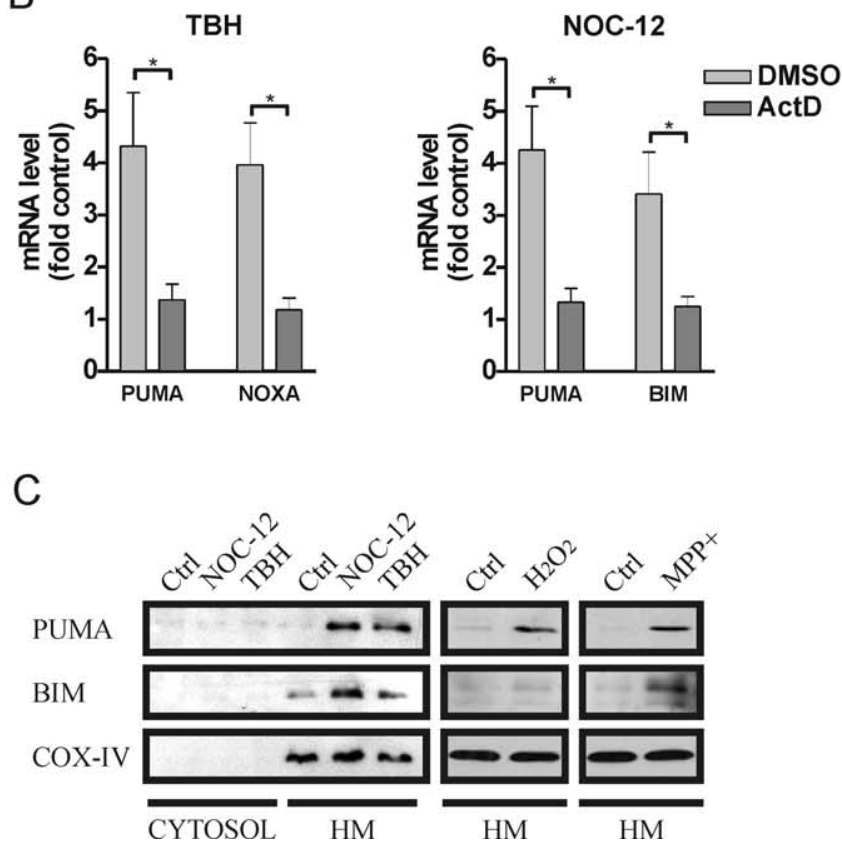

Figure 2. Oxidative stress induces the expression of the BH3-only members Bim, Noxa, and Puma. $\boldsymbol{A}$, RNA was isolated from cortical neurons at the indicated times after treatment with TBH $(200 \mu \mathrm{M}), \mathrm{H}_{2} \mathrm{O}_{2}(20 \mu \mathrm{m}), \mathrm{NOC}-12(200 \mu \mathrm{m})$ or MPP $+(100 \mu \mathrm{M})$ and $\mathrm{mRNA}$ levels of $\mathrm{BCl}-2$ family members was determined by quantitative RT-PCR. Expression was normalized to $S 12 \mathrm{mRNA}$ levels and is reported as fold increase over corresponding untreated control cells $(n \geq 4)$. Asterisks indicate significant increase in mRNA level in treated versus untreated neurons for each transcript $\left({ }^{*} p<0.05\right)$. $\boldsymbol{B}$, Neurons were treated with TBH $(200 \mu \mathrm{m})$ or NOC -12 $(200 \mu \mathrm{m})$ in the presence of ActD (5 $\mu \mathrm{g} / \mathrm{ml})$ or DMSO (solvent control) and after $10 \mathrm{~h}$ the fold increase in Puma, Noxa, and Bim mRNA was determined by $q R T-P C R\left(n=3{ }^{*} p<0.05\right)$. C, Bax-deficient cortical neurons were treated with NOC-12 $(200 \mu \mathrm{M}), \mathrm{TBH}$ $(200 \mu \mathrm{M}), \mathrm{H}_{2} \mathrm{O}_{2}(20 \mu \mathrm{M})$, or MPP $+(100 \mu \mathrm{M})$ and after $24 \mathrm{~h}$ (or $48 \mathrm{~h}$ in the case of MPP + ) Puma and Bim protein levels were assessed in the cytosolic and HM fractions by Western blot analysis. 
A
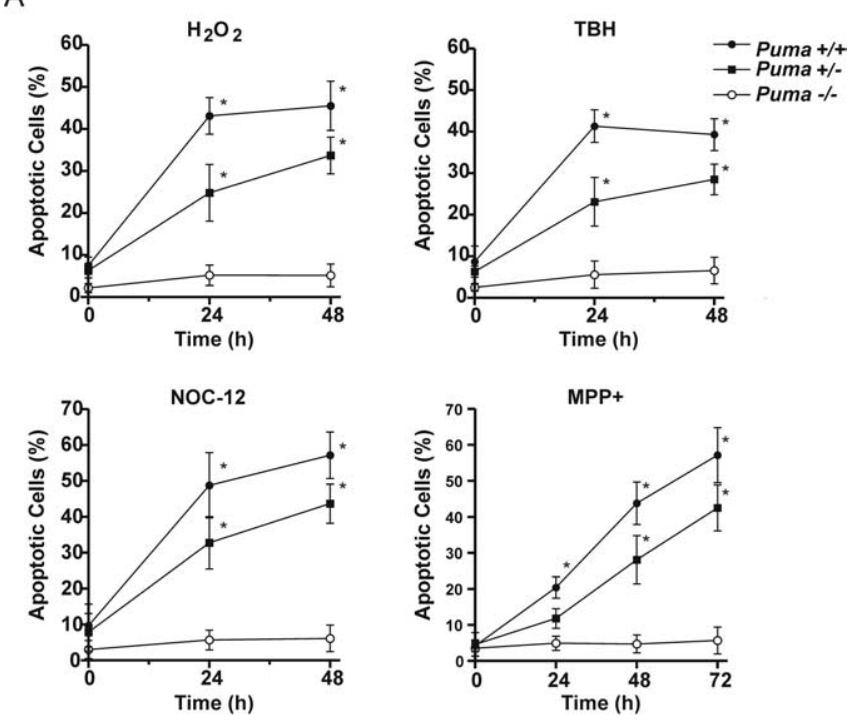

B

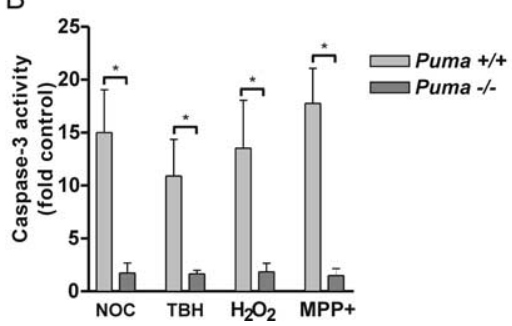

Figure 3. Puma is essential for oxidative stress induced neuronal apoptosis. $A$, Cortical neurons cultured from wt, Puma ${ }^{+/-}$, and Puma ${ }^{-/-}$littermates were treated with TBH $(200 \mu \mathrm{M})$, $\mathrm{H}_{2} \mathrm{O}_{2}(20 \mu \mathrm{M}), \mathrm{NOC}-12(200 \mu \mathrm{m})$, or MPP $+(100 \mu \mathrm{m})$, and the fraction of apoptotic cells was determined by Hoechst 33258 staining at the indicated times $(n \geq 6)$. Asterisks indicate significant increase over untreated neurons of the same genotype $\left({ }^{*} p<0.01\right) . B$, Wt and $\mathrm{Pu}$ $\mathrm{ma}^{-1-}$ neurons were treated with oxidative stressors as above and assayed for caspase- 3 activity at $24 \mathrm{~h}$ (or $40 \mathrm{~h}$ in the case of MPP + treatment) $\left(n=4 ;{ }^{*} p<0.01\right)$.

\section{Puma is essential for oxidative stress induced neuronal apoptosis}

Because the $\mathrm{BH} 3$-only proteins Bim, Noxa, and Puma were selectively induced by oxidative stress, we sought to determine whether these proteins contributed to neuronal cell death. We first examined the potential role of Puma as it was upregulated in response to several different types of reactive oxygen species. We treated $\mathrm{Puma}^{+/+}$(wt), Puma ${ }^{+/-}$, and $\mathrm{Puma}^{-/-}$neurons with NOC-12, $\mathrm{H}_{2} \mathrm{O}_{2}, \mathrm{TBH}$, or MPP + and measured the extent of apoptosis as a function of time (Fig. $3 A$ ). In contrast to wt and Puma $^{+/-}$neurons, treatment of Puma $^{-/-}$neurons with these different oxidative stressors did not result in a significant induction of apoptosis relative to untreated controls even after 48-72 h. Consistent with the marked reduction in apoptotic cells, caspase-3 like activity was also found to be dramatically reduced in $\mathrm{Puma}^{-/-}$neurons (Fig. $3 \mathrm{~B}$ ). It was also noted that the apoptotic frequency was generally reduced in $\mathrm{Puma}^{+/-}$neurons as compared with wt neurons suggesting a possible gene dosage effect (Fig. 3A).

To rule out the possibility that $\mathrm{Puma}^{-/-}$neurons were dying via an alternative (nonapoptotic) mechanism, we also measured neuronal survival in $\mathrm{Puma}^{+/+}$and $\mathrm{Puma}^{-/-}$neurons by CalceinAM/ethidium homodimer staining (live/dead assay). As shown in Figure $4 A$, treatment with NOC-12, TBH, or MPP + reduced survival of wt neurons at $48 \mathrm{~h}$ to $38.7,45.3$, and $46.4 \%$, respec- tively. In contrast, after these same treatments survival of $\mathrm{Pu}$ $m a^{--}$neurons remained similar to untreated controls at $>90 \%$ indicating that Puma-deficient neurons were not dying via an alternate mechanism. Furthermore, MAP-2 immunostaining revealed that unlike wt neurons the vast majority of $\mathrm{Puma}^{-/-}$neurons maintained their neuritic extensions after exposure to oxidative stress (Fig. 4B).

We next examined whether Puma-deficient neurons remain functional after oxidative damage. Individual pyramidal neurons are known to respond to hyperpolarizing and depolarizing voltage in a characteristic manner in culture (Hutcheon et al., 2000). Therefore, we performed patch-clamp recordings to determine whether Puma-deficient neurons retain their electrophysiological properties after oxidative injury. In untreated wt and $\mathrm{Pu}$ $\mathrm{ma}^{-/-}$neurons we found the peak sodium current to have a density of $23.2 \pm 9.8 \mathrm{pA} / \mathrm{um}^{2}$ and $22.3 \pm 7.8 \mathrm{pA} / \mu \mathrm{m}^{2}$, respectively (Fig. 4C). The magnitude of the sodium current in $\mathrm{Pu}$ $\mathrm{ma}^{-/-}$neurons treated with NOC-12 was found to be $17.9 \pm 4.2$ $\mathrm{pA} / \mu \mathrm{m}^{2}$ and this was not significantly different from untreated control neurons $(p=0.29)$. However, the vast majority of wt neurons treated with NOC-12 had undergone cell death at this point and the few surviving neurons were too fragile to obtain stable recordings. Thus, Puma-deficient neurons appear to retain normal voltage dependent current activity after oxidative injury. Cortical neurons in culture are also known to make functional synaptic connections, and so we assayed the spontaneous synaptic activity in these cultures (Fig. 4D). We found that the activity between the untreated and NOC-12 treated $\mathrm{Puma}^{-/-}$neurons was also indistinguishable. The frequency of spontaneous events in untreated wt, untreated $\mathrm{Puma}^{-/-}$, and NOC-12-treated $\mathrm{Pu}$ $\mathrm{ma}^{-/-}$cultures was $1.7 \pm 0.6,1.1 \pm 0.2$ and $1.2 \pm 0.3 \mathrm{~Hz}$, respectively $(p=0.65$ ). Overall our data indicate that Puma-deficient neurons survive and retain normal neuronal function after oxidative injury.

Because the BH3-only family members Bim and Noxa were also induced by oxidative stress, we then examined whether they also contribute to neuronal cell death. As shown in Figure $5 A$ and $5 \mathrm{~B}, \mathrm{NOC}-12$, and MPP + treatments induced similar levels of apoptosis and caspase activity in wt and $\mathrm{Bim}^{-/-}$neurons. Likewise, we observed no significant change in caspase activity or apoptotic frequency in wt and $\mathrm{Noxa}^{-/-}$neurons after treatment with $\mathrm{H}_{2} \mathrm{O}_{2}$ or TBH (Fig. $5 C, D$ ). Thus, although Puma, Bim, and Noxa expression is induced in response to oxidative stress, only Puma induction appears to be essential for cell death.

\section{Puma regulates Bax activation after oxidative injury}

$\mathrm{BH} 3$-only proteins are thought to co-operate with multidomain proapoptotic Bcl-2-family members to induce apoptosis (Harris and Johnson, 2001; Zong et al., 2001). Consistent with this we have determined that similar to Puma-deficient neurons, Baxdeficient neurons are remarkably resistant to oxidative stress induced apoptosis (Fig. 6A). Therefore, to address the mechanism responsible for the different effects of Puma, Bim and Noxa on neuronal cell death we examined whether these $\mathrm{BH} 3$-only proteins differentially affect Bax activation. In response to apoptotic stimuli, Bax is known to translocate from the cytoplasm to the mitochondrial membrane (Wolter et al., 1997; Goping et al., 1998). As shown in Figure $6 B$, in wt neurons treatment with NOC-12 or TBH decreased Bax levels in the cytosolic fraction and simultaneously increased the amount of Bax associated with the heavy membrane fraction consistent with its translocation to the mitochondria. However, these oxidative treatments did not appreciably alter the distribution of Bax in $\mathrm{Puma}^{-1-}$ neurons, 
indicating that Puma is required for Bax translocation. In contrast, neither Bimdeletion nor Noxa-deletion prevented oxidative stress induced Bax translocation to the mitochondria (Fig. 6C). During activation Bax is known to undergo a conformational change that exposes an epitope within its $\mathrm{N}$ terminus that is recognized by the 6A7 monoclonal antibody (Hsu and Youle, 1998). Consistent with a requirement for Puma in mediating oxidative stress induced Bax activation we found that immunoprecipitation of Bax with the 6A7 antibody was markedly reduced in Puma $-/-$ neuronal extracts as compared with wt extracts (Fig. 6D). Finally, as a measure of Bax function we also examined the effect of Puma, Bax, Bim, and Noxa deletion on oxidative stress induced mitochondrial membrane permeabilization. We and others have shown previously that cytochrome-c immunoreactivity is rapidly lost in neurons after its release from the mitochondria and therefore can be used as an effective measure of outer membrane permeabilization (Deshmukh and Johnson, 1998; Neame et al., 1998; Cregan et al., 2002). In wt neurons, treatment with NOC-12, TBH, $\mathrm{H}_{2} \mathrm{O}_{2}$, or MPP+ led to a marked reduction in the fraction of cells retaining mitochondrial cytochrome-c as compared with untreated control cells (Fig. 7). However, after these same treatments the vast majority $(>90 \%)$ of $\mathrm{Pu}$ $\mathrm{ma}^{-1-}$ and $\mathrm{Bax}^{-1-}$ neurons retained mitochondrial cytochrome-c indicating that Puma and Bax cooperate to induce mitochondrial membrane permeabilization. In contrast, neither Bim deletion nor Noxa deletion prevented oxidative stress induced cytochrome-c release (Fig. 7).

To determine whether Puma is sufficient to induce Bax activation we transduced wt and $\mathrm{Bax}^{-/-}$neurons with recombinant adenoviruses (Ad) expressing Puma (Ad-PUMA) or GFP (Ad-GFP) as a control. As illustrated in Figure $8 A$, enforced expression of Puma significantly enhanced the amount of Bax immunoprecipitated with the activated conformation specific antibody (6A7) consistent with the induction of Bax activation. Furthermore, we found that enforced expression of Puma could induce cytochrome-c release and caspase activation in wt neurons, but not $B a x^{-1-}$ neurons (Fig. $8 B, C$ ). Together these results suggest that Puma is both necessary and sufficient to induce Bax activation in neurons.

$\mathrm{BH} 3$-only proteins are generally thought to promote apoptosis by binding to and neutralizing anti-apoptotic Bcl-2 family members (Moreau et al., 2003). However, it has been suggested that certain $\mathrm{BH} 3$-only proteins may also directly interact with multidomain proapoptotic members to promote their apoptotic function (Eskes et al., 2000; Letai, 2002; Kuwana et al., 2005). Because Puma, but not Noxa or Bim, appears to be essential for oxidative stress induced Bax activation we explored the possibility that in addition to interacting with anti-apoptotic Bcl-2 proteins, Puma may interact with Bax. To address this question, we
B
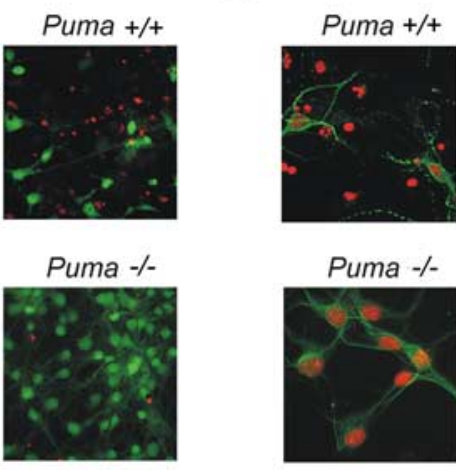

NOC-12

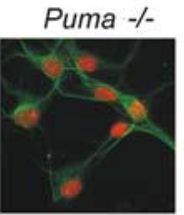

NOC-12 $(48 \mathrm{~h})$

Figure 4. Puma-deficient neurons remain functional after oxidative injury. $\boldsymbol{A}, \mathrm{Wt}$ and $P u m a^{-/}$- neurons were treated with

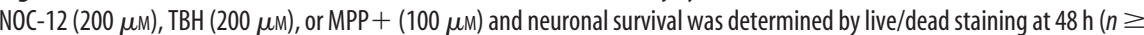
counterstained with Hoechst 33258 (pseudocolored orange). C, Voltage-clamp recordings were performed on untreated neurons steady state $(n \geq 9)$. $\boldsymbol{D}$, Representative recordings of spontaneous activity in untreated (wt and Puma $-/-$ ) neurons and NOC-12-treated Puma ${ }^{-1-}$ neurons.

examined the ability of GST-Puma and GST-Bim EL $_{\text {to }}$ pulldown Bax or the anti-apoptotic member Bcl- $\mathrm{X}_{\mathrm{L}}$ from cell lysates obtained from NOC-12 treated $\mathrm{Puma}^{-/-}$cortical neurons. Extracts from Puma $^{-1-}$ neurons were used in these experiments to avoid potential complications associated with cell death. As shown in Figure 9A, GST-Puma precipitated both endogenous Bcl- $\mathrm{X}_{\mathrm{L}}$ and Bax with high efficiency. These interactions were specific for Puma as binding was not observed in pulldowns performed with GST alone. In contrast, GST-Bim ${ }_{\mathrm{EL}}$ efficiently precipitated Bcl$\mathrm{X}_{\mathrm{L}}$, but not Bax (Fig. 9B). These results suggest that Puma may play a dominant role in regulating Bax activation and neuronal apoptosis by associating with $\mathrm{Bax}$ and targeting it to the mitochondria.

\section{p53 is a key regulator of oxidative stress induced puma} expression and neuronal cell death

We have shown previously that Puma is a key transcriptional target in p53 mediated neuronal cell death (Cregan et al., 2004a). Therefore, we examined whether $\mathrm{p} 53$ regulates Puma induction and neuronal apoptosis in response to oxidative stress. As shown 
A

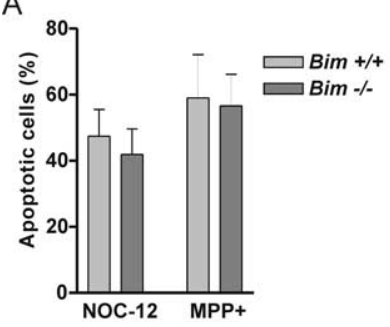

B

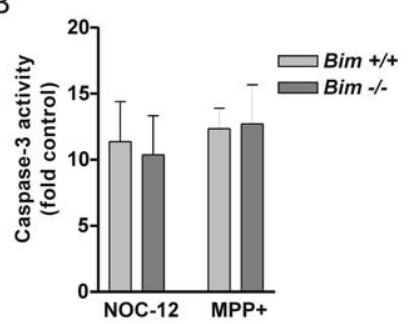

C

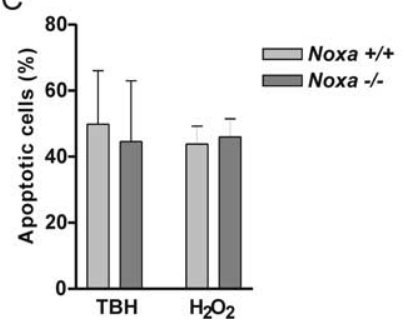

D

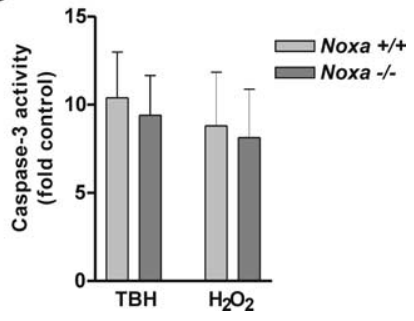

Figure 5. Bim and Noxa are not required for oxidative stress induced neuronal apoptosis. $\boldsymbol{A}$, Wt and Bim ${ }^{-1-}$ neurons were treated with NOC-12 (200 $\left.\mu \mathrm{m}\right)$ or MPP $+(100 \mu \mathrm{m})$ and the fraction of apoptotic cells was determined by Hoechst staining at 24 and $48 \mathrm{~h}$, respectively ( $n \geq$ 4). $\boldsymbol{B}, \mathrm{Wt}$ and $\mathrm{Bim}^{-/-}$neurons were treated as above and caspase-3 activity was assayed at $24 \mathrm{~h}$ $(\mathrm{NOC}-12)$ or $48 \mathrm{~h}(\mathrm{MPP}+)(n=3) . \mathrm{C}, \mathrm{Wt}$ and Noxa ${ }^{-/-}$neurons were treated with TBH (200 $\mu \mathrm{m})$ or $\mathrm{H}_{2} \mathrm{O}_{2}(20 \mu \mathrm{m})$ and the fraction of apoptotic cells was determined by Hoechst staining at $24 \mathrm{~h}(n \geq 3)$. D, Wt and Noxa ${ }^{-/-}$neurons were treated with TBH $(200 \mu \mathrm{m}) \mathrm{orH}_{2} \mathrm{O}_{2}(20 \mu \mathrm{m})$ and caspase-3 activity was assayed aft $24 \mathrm{~h}(n=3)$.

in Figure $10 A$, the induction of Puma expression in response to various oxidative stressors was decreased in $p 53^{-/-}$neurons as compared with wt neurons. Furthermore, we found that $\mathrm{TBH}$, $\mathrm{H}_{2} \mathrm{O}_{2}$, and NOC-12 induced apoptosis was significantly diminished in $p 53^{-/-}$cortical neurons (Fig. $10 \mathrm{~B}$ ). Together these results indicate that p53 is a key regulator of oxidative damage induced Puma expression and neuronal cell death.

\section{Discussion}

\section{Puma is required for oxidative stress induced} neuronal apoptosis

It is widely recognized that apoptosis contributes to the neurological dysfunction that occurs in acute neuronal injuries and in certain neurodegenerative diseases (Vila and Przedborski, 2003; Chan, 2004). A multitude of studies implicate oxidative stress as a major trigger for neuronal cell death in these neurodegenerative conditions (Sugawara and Chan, 2003; Andersen, 2004). Indeed, elevated levels of several reactive oxidant species have been reported in animal models of cerebral ischemia and neurodegenerative disease, and oxidative damage has been observed in postmortem tissue of affected humans (Lyras et al., 1998; Eliasson et al., 1999; Hsu et al., 2000). Furthermore, it has been demonstrated that free radical reducing agents are neuroprotective in animal models of cerebral ischemia, and that transgenic mice that overexpress the antioxidant enzymes superoxide-dismutase (SOD1) or glutathione peroxidase (GSHPX) exhibit reduced infarct volumes (Margaill et al., 2005). Likewise, it has been shown that neuronal cell death is enhanced in SOD1- and GSHPXdeficient mice in the MPTP model of Parkinson's disease as well as in models of ischemic injury (Zhang et al., 2000; Crack et al., 2001). Importantly, we have determined that transcriptional induction of the Bcl-2 family member Puma is essential for oxidative stress induced neuronal apoptosis suggesting that Puma may be an important therapeutic target for the treatment of several

neurodegenerative conditions. Interestingly, it has been reported that after cerebral ischemia in rat, Puma expression is upregulated in regions of the hippocampus known to exhibit significant levels of apoptosis, suggesting that Puma may be an important target in stroke (Reimertz et al., 2003). Previous data also suggests that Puma may contribute to neuronal cell death in Parkinson's disease. For example, Puma has been implicated in apoptosis in PC12 cells induced by the Parkinson's related toxin 6-hydroxydopamine (Biswas et al., 2005). Furthermore, in the present study we demonstrated that Puma-deficient neurons are remarkably resistant to cell death induced by $\mathrm{MPP}+$, the active metabolite of the Parkinson inducing agent MPTP. However, it will be important in future studies to assess the role of Puma in dopaminergic neuron cell death in animal models of Parkinson's disease in vivo.

The $\mathrm{BH} 3$-only subgroup of the $\mathrm{Bcl}-2$ protein family consists of multiple family members that could potentially contribute to neuronal cell death. In addition to Puma, oxidative stress triggered induction of the $\mathrm{BH} 3$-only member $\mathrm{Bim}_{\mathrm{EL}}$. However, Bimdeletion did not affect oxidative stress induced mitochondrial permeabilization, caspase activation, or neuronal cell death. This was curious as $\mathrm{Bim}_{\mathrm{EL}}$ has been reported to contribute to the induction of neuronal apoptosis after NGF deprivation, potassium/ serum deprivation, and p75NTR signaling (Putcha et al., 2001; Whitfield et al., 2001; Becker et al., 2004). In these developmental neuronal death paradigms Jun N-terminal kinase-mediated phosphorylation of $\mathrm{Bim}_{\mathrm{EL}}$ has been shown to promote its apoptotic activity (Putcha et al., 2003; Becker et al., 2004). However, it has been shown that phosphorylation of Bim by ERK1/2 in non-neuronal cells can promote its ubiquitination and degredation and thereby reduce its apoptotic activity (Ley et al., 2003; Harada et al., 2004). Although we have not determined whether oxidative stress affects the phosphorylation status of $\mathrm{Bim}_{\mathrm{EL}}$, we found that $\operatorname{Bim}_{\mathrm{EL}}$ localized to the mitochondria and was able to bind to $\mathrm{Bcl}-\mathrm{X}$, suggesting that this is not sufficient to promote neuronal apoptosis in the absence of Puma.

In addition to Bim and Puma, we also observed a robust induction of Noxa mRNA in response to certain types of oxidative stress. However, similar to Bim-deficient neurons, Noxa-deficient neurons were not protected against oxidative stress-induced cell death. Consistent with this, we have shown previously that Noxa is upregulated in cortical and cerebellar granule neurons after DNA damage or enforced expression of $\mathrm{p} 53$, but that ectopic expression of Noxa was not sufficient to induce neuronal apoptosis (Cregan et al., 2004a). Similarly, it has been shown previously that Noxa mRNA levels are induced after DNA damage in sympathetic neurons, but that cell death was not diminished in the absence of Noxa (Wyttenbach and Tolkovsky, 2006). However, it has been reported that axotomy induced motor neuron cell death is reduced in Noxa-deficient mice (Kiryu-Seo et al., 2005). Therefore, it is possible that Noxa may function in certain neuronal populations, but not others. We also recognize that $\mathrm{BH} 3$-only proteins activated through transcriptionindependent mechanisms might also contribute to oxidative stress induced neuronal apoptosis. For example, Bid is known to be activated in response to death receptor (e.g., Fas) activation when cleaved by caspase- 8 into its truncated form tBid (Li et al., 1998). Interestingly, tBid has been implicated in neuronal cell death induced by oxygen-glucose deprivation and in a rodent model of focal ischemia (Plesnila et al., 2001). Although we cannot rule out the possible involvement of Bid or other post-translationally activated $\mathrm{BH} 3$-only family members our results indicate that regardless of the their potential contribution, Puma induction is essential for cell death. 
Puma regulates Bax activation in response to oxidative damage $\mathrm{BH} 3$-only proteins are thought to function by promoting the activity of multidomain proapoptotic Bcl-2 family members (Harris and Johnson, 2001; Zong et al., 2001). Indeed we have demonstrated that not only Puma but also Bax is required for mitochondrial outer membrane permeabilization and neuronal apoptosis in response to oxidative injury. Furthermore, we have determined that Puma is required for oxidative stress induced Bax translocation and conversion of Bax to its activated conformation. Moreover, we found that ectopic expression of Puma is sufficient to induce Bax activation and to trigger Baxmediated mitochondrial membrane permeabilization. Together, these results suggest that Puma is a key regulator of Bax activation in response to oxidative damage.

It is generally thought that $\mathrm{BH} 3$-only proteins function by binding and neutralizing anti-apoptotic family members (Moreau et al., 2003). Interestingly, it has been reported that certain $\mathrm{BH} 3$-only proteins can bind to multiple prosurvival Bcl-2 family members whereas others are more restricted (Chen et al., 2005). Moreover, the authors of this study indicated that the cytotoxic potential of different $\mathrm{BH} 3$-only proteins when ectopically expressed correlates with their degree of promiscuity. For example, it was shown that Noxa interacts with Mcl-1, but not other prosurvival members including $\mathrm{Bcl}-\mathrm{x}_{\mathrm{L}}$ or Bcl-2 and as a result has limited cell killing potential. This is consistent with our previous findings demonstrating that ectopic expression of Noxa is not sufficient to induce neuronal apoptosis (Cregan et al., 2004a), and our current findings that although Noxa is induced by oxidative stress, its sole loss does not inhibit cell death. However, it was shown that both Puma and Bim exhibit high affinity for all prosurvival Bcl-2 family proteins (Chen et al., 2005). However, we found that Puma-deletion but not Bim-deletion prevents oxidative stress induced Bax activation and neuronal apoptosis indicating that Puma and Bim do not perform redundant functions in this context. Although controversial, it has been suggested that in addition to neutralizing prosurvival members certain $\mathrm{BH} 3$-only proteins may also directly interact with multidomain proapoptotic members to promote their activity (Eskes et al., 2000; Letai, 2002; Kuwana et al., 2005; Kim et al., 2006; Willis et al., 2007). Indeed, we have demonstrated using GST-pulldown assays that Puma but not Bim can associate with Bax in cell extracts isolated from neurons exposed to oxidative stress. However, we cannot rule out the possibility that Puma associates with Bax as part of a complex and not through direct physical interaction. Unfortunately, we were unable to examine the interaction between Puma and Bax after oxidative
B

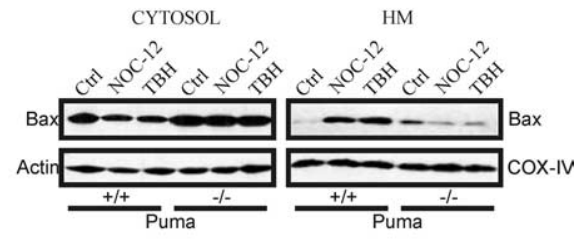

D

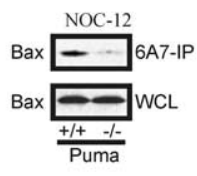

Figure 6. Puma is required for oxidative stress induced Bax activation. $A, \mathrm{Wt}$ and $B a x^{-/-}$neurons were treated with NOC-12 $(200 \mu \mathrm{M}), \mathrm{TBH}(200 \mu \mathrm{M}), \mathrm{H}_{2} \mathrm{O}_{2}(20 \mu \mathrm{M})$, or MPP $+(100 \mu \mathrm{M})$ and the fraction of apoptotic cells was determined by Hoechst staining at $48 \mathrm{~h}\left(n \geq 5 ;{ }^{*} p<0.001\right)$. B , Wt and Puma ${ }^{-/-}$neurons were treated with NOC-12 (200 $\left.\mu \mathrm{M}\right)$ or TBH $(200 \mu \mathrm{m})$ and after $24 \mathrm{~h}$ Bax protein levels were assessed in cytosolic and HM fractions by Western blot analysis. Immunoblots for $\beta$-Actin and COX-IV are shown for normalization of cytosolic and heavy membrane fractions respectively. C, Wt, $\mathrm{Bim}^{-1-}$, and Noxa ${ }^{-/-}$neurons were treated with NOC-12 $(200 \mu \mathrm{m})$ or TBH $(200 \mu \mathrm{m})$ and after $24 \mathrm{~h}$ Bax protein levels were assessed in the HM fraction by Western blot. D. Wt and Puma ${ }^{-1-}$ neurons were treated with NOC-12 (200 $\left.\mu \mathrm{m}\right)$ and after $24 \mathrm{~h}$ Bax was immunoprecipitated from neuronal extracts with an antibody that specifically recognizes activated Bax (6A7). Immunoprecipitates (IP) and whole-cell lysates (WCL) were resolved by SDS-PAGE and immunoblotted for Bax. WCL represents $20 \%$ of protein used in IP reaction.
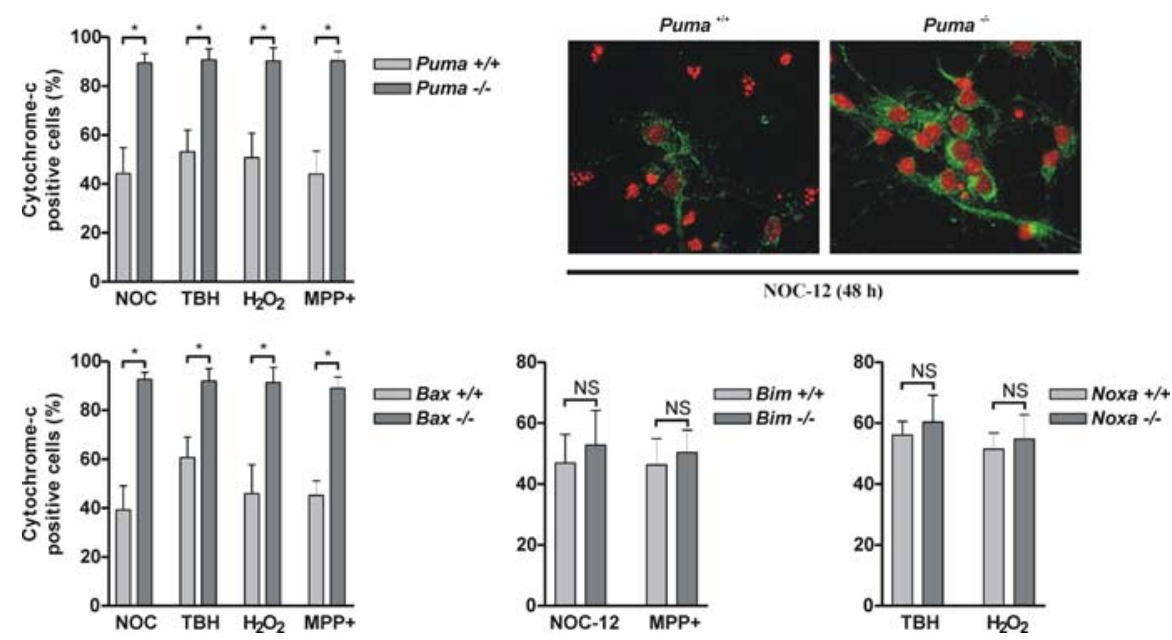

Figure 7. Puma and Bax cooperate to regulate oxidative stress induced mitochondrial membrane permeabilization. Cortical neurons derived from Puma ${ }^{+/+}$and Puma ${ }^{-/-}$littermates $\left(n=4 ;{ }^{*} p<0.001\right), B a x^{+/+}$, and Bax ${ }^{-/-}$littermates $\left(n=4 ;{ }^{*} p<0.001\right), B i m^{+/+}$and Bim ${ }^{-/-}$littermates $(n \geq 3)$ and Noxa ${ }^{+/+}$and Noxa $a^{-/-}$littermates $(n=3)$ were treated with NOC-12 $(200 \mu \mathrm{M}), \mathrm{H}_{2} \mathrm{O}_{2}(20 \mu \mathrm{M}), \mathrm{TBH}(200 \mu \mathrm{m})$, or MPP $+(100 \mu \mathrm{M})$ and the fraction of cells retaining mitochondrial cytochrome-c was determined at $24 \mathrm{~h}$ (or $48 \mathrm{~h}$ in the case of MPP + ). Representative images of wt and Puma $^{-1-}$ neurons treated for $24 \mathrm{~h}$ with NOC-12 (200 $\left.\mu \mathrm{m}\right)$ and immunostained for cytochrome-c (green) and counterstained with Hoechst (pseudocolored orange).

stress in situ as Puma protein levels were only appreciably elevated in Bax-deficient neurons presumably because of its potent cell killing capacity. These results suggest that Puma could play a dominant role in regulating neuronal cell death by virtue of its ability to both neutralize anti-apoptotic $\mathrm{Bcl}-2$ proteins and directly promote Bax activation.

Oxidative stress triggers Puma induction and neuronal cell death via p53-dependent and p53-independent mechanisms In this study, we demonstrate that the transcriptional activator p53 plays a key role in regulating oxidative stress induced Puma expression and neuronal apoptosis. Consistent with this 
A

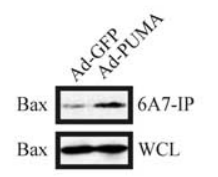

B

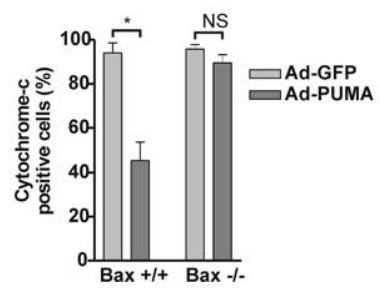

C

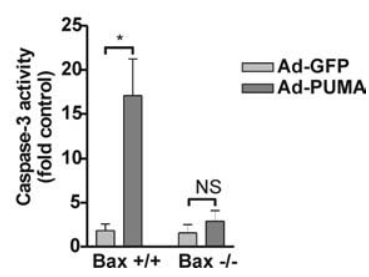

Figure 8. Puma expression is sufficient to induce Bax activation. $A$, Neurons were transduced with Ad-Puma or Ad-GFP at 20 multiplicity of infection and after $24 \mathrm{~h}$ Bax was immunoprecipitated from neuronal extracts with an antibody (6A7) that specifically recognizes activated Bax. Immunoprecipitates (IP) and whole-cell lysates (WCL) were resolved by SDS-PAGE and immunoblotted for Bax. WCL represents $20 \%$ of protein used in IP reaction. $B$, Wt and $B a x-/-$ neurons were transduced with Ad-Puma or Ad-GFP and the fraction of cells retaining mitochondrial cytochrome-c was measured after $40 \mathrm{~h}\left(n=3 ;{ }^{*} p<0.001\right)$. C Caspase-3 activity was measured $40 \mathrm{~h}$ after transduction with Ad-Puma or Ad-GFP $\left(n=3 ;{ }^{*} p<0.01\right)$.

A

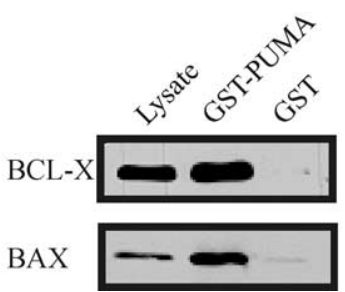

B

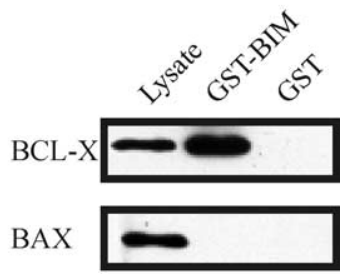

Figure 9. Puma physically associates with $\mathrm{BCl}-\mathrm{X}_{\mathrm{L}}$ and Bax. $\boldsymbol{A}, \boldsymbol{B}$, Lysates from Puma ${ }^{-/-}$ neurons were incubated with GST-Puma $(\boldsymbol{A})$ or GST-Bim EL $_{\mathrm{L}}(\boldsymbol{B})$ and complexes were precipitated with glutathione-sepharose beads. Binding of GST-Puma or GST-Bim to BCl- $X_{L}$ and Bax was determined by immunoblot. Lanes labeled lysate correspond to $10 \%$ of protein used in pulldown assay.

A

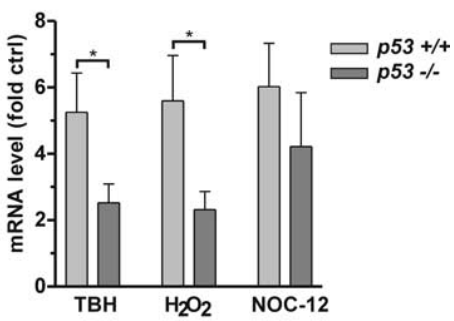

B

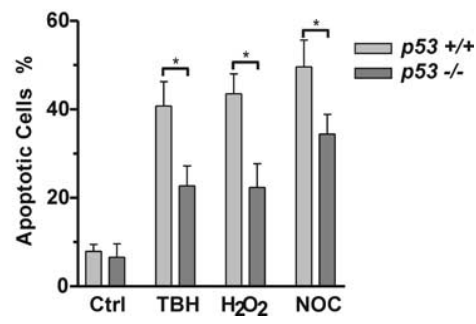

Figure 10. $\quad \mathrm{p} 53$ is a key regulator of oxidative stress induced Puma expression and neuronal cell death. $A$, Cortical neurons from wt and p53-/ - littermates were treated with TBH (200 $\mu \mathrm{M}), \mathrm{H}_{2} \mathrm{O}_{2}(20 \mu \mathrm{M})$ or NOC-12 $(200 \mu \mathrm{M})$ and Puma mRNA induction was determined by quantitative RT-PCR after $10 \mathrm{~h}\left(n=6 ;{ }^{*} p<0.01\right) . \boldsymbol{B}$, Wt and $p 53-/-$ neurons were treated with the indicated oxidative stressors and the fraction of apoptotic cells was determined by Hoechst staining after $24 \mathrm{~h}\left(n=5 ;{ }^{*} p<0.01\right)$.

we have previously demonstrated that Puma is an essential transcriptional target in p53 mediated neuronal cell death (Cregan et al., 2004a). The contribution of p53 in this setting likely reflects the ability of oxidative stress associated free radicals to induce DNA damage. Indeed, previous studies have demonstrated that p53 is a critical regulator of DNA damage

induced neuronal apoptosis (Wood and Youle, 1995; Xiang et al., 1996; Enokido et al., 1996). Interestingly, however, we found that the induction of Puma and neuronal apoptosis after oxidative injury was only partially blocked in $p 53^{-1-}$ neurons suggesting that other factors also contribute to these processes. At this stage the nature of the p53-independent activation pathway remains unclear, although several interesting candidates exist. For example, it has been reported that in colorectal cancer cells Puma expression can be induced by the p53family member p73 (Melino et al., 2004). Another group has shown that the transcription factor E2F1 can bind to the Puma promoter and drive its expression in fibroblasts (Hershko and Ginsberg, 2004). Most recently, it was reported that Foxo3a can activate Puma expression in hematopoietic cells after cytokine deprivation (You et al., 2006). Therefore, in future studies it will be important to identify additional transcriptional activators that contribute to oxidative stress induced Puma induction and neuronal cell death. In summary, we have established that Puma is a dominant regulator of oxidative stress induced Bax activation and neuronal apoptosis suggesting that Puma may be a key therapeutic target for neuroprotection.

\section{References}

Andersen JK (2004) Oxidative stress in neurodegeneration: cause or consequence? Nat Med [Suppl] 10:S18-S25.

Aslan M, Ozben T (2004) Reactive oxygen and nitrogen species in Alzheimer's disease. Curr Alzheimer Res 1:111-119.

Becker EB, Howell J, Kodama Y, Barker PA, Bonni A (2004) Characterization of the c-Jun $\mathrm{N}$-terminal kinase-Bim $\mathrm{EL}_{\mathrm{EL}}$ signaling pathway in neuronal apoptosis. J Neurosci 24:8762-8770.

Biswas SC, Ryu E, Park C, Malagelada C, Greene LA (2005) Puma and p53 play required roles in death evoked in a cellular model of Parkinson disease. Neurochem Res 30:839-845.

Bouillet P, Metcalf D, Huang DC, Tarlinton DM, Kay TW, Kontgen F, Adams JM, Strasser A (1999) Proapoptotic Bcl-2 relative Bim required for certain apoptotic responses, leukocyte homeostasis, and to preclude autoimmunity. Science 286:1735-1738.

Chan PH (2004) Mitochondria and neuronal death/survival signaling pathways in cerebral ischemia. Neurochem Res 29:1943-1949.

Chen L, Willis SN, Wei A, Smith BJ, Fletcher JI, Hinds MG, Colman PM, Day CL, Adams JM, Huang DC (2005) Differential targeting of prosurvival $\mathrm{Bcl}-2$ proteins by their $\mathrm{BH} 3$-only ligands allows complementary apoptotic function. Mol Cell 17:393-403.

Crack PJ, Taylor JM, Flentjar NJ, de HJ, Hertzog P, Iannello RC, Kola I (2001) Increased infarct size and exacerbated apoptosis in the glutathione peroxidase-1 (Gpx-1) knockout mouse brain in response to ischemia/ reperfusion injury. J Neurochem 78:1389-1399.

Cregan SP, Maclaurin JG, Craig CG, Robertson GS, Nicholson DW, Park DS, Slack RS (1999) Bax-dependent caspase-3 activation is a key determinant in p53-induced apoptosis in neurons. J Neurosci 19:7860-7869.

Cregan SP, Fortin A, Maclaurin JG, Callaghan SM, Cecconi F, Yu SW, Dawson TM, Dawson VL, Park DS, Kroemer G, Slack RS (2002) Apoptosisinducing factor is involved in the regulation of caspase-independent neuronal cell death. J Cell Biol 158:507-517.

Cregan SP, Arbour NA, Maclaurin JG, Callaghan SM, Fortin A, Cheung EC, Guberman DS, Park DS, Slack RS (2004a) p53 activation domain 1 is essential for PUMA upregulation and p53-mediated neuronal cell death. J Neurosci 24:10003-10012.

Cregan SP, Dawson VL, Slack RS (2004b) Role of AIF in caspase-dependent and caspase-independent cell death. Oncogene 23:2785-2796.

Deshmukh M, Johnson Jr EM (1998) Evidence of a novel event during neu- 
ronal death: development of competence-to-die in response to cytoplasmic cytochrome c. Neuron 21:695-705.

Eliasson MJ, Huang Z, Ferrante RJ, Sasamata M, Molliver ME, Snyder SH, Moskowitz MA (1999) Neuronal nitric oxide synthase activation and peroxynitrite formation in ischemic stroke linked to neural damage. J Neurosci 19:5910-5918.

Enokido Y, Araki T, Tanaka K, Aizawa S, Hatanaka H (1996) Involvement of p53 in DNA strand break-induced apoptosis in postmitotic CNS neurons. Eur J Neurosci 8:1812-1821.

Eskes R, Desagher S, Antonsson B, Martinou JC (2000) Bid induces the oligomerization and insertion of Bax into the outer mitochondrial membrane. Mol Cell Biol 20:929-935.

Fallon J, Matthews RT, Hyman BT, Beal MF (1997) MPP+ produces progressive neuronal degeneration which is mediated by oxidative stress. Exp Neurol 144:193-198.

Fortin A, Cregan SP, Maclaurin JG, Kushwaha N, Hickman ES, Thompson CS, Hakim A, Albert PR, Cecconi F, Helin K, Park DS, Slack RS (2001) APAF1 is a key transcriptional target for p53 in the regulation of neuronal cell death. J Cell Biol 155:207-216.

Gastard MC, Troncoso JC, Koliatsos VE (2003) Caspase activation in the limbic cortex of subjects with early Alzheimer's disease. Ann Neurol 54:393-398.

Goping IS, Gross A, Lavoie JN, Nguyen M, Jemmerson R, Roth K, Korsmeyer SJ, Shore GC (1998) Regulated targeting of BAX to mitochondria. J Cell Biol 143:207-215.

Harada H, Quearry B, Ruiz-Vela A, Korsmeyer SJ (2004) Survival factorinduced extracellular signal-regulated kinase phosphorylates BIM, inhibiting its association with BAX and proapoptotic activity. Proc Natl Acad Sci USA 101:15313-15317.

Harris CA, Johnson Jr EM (2001) BH3-only Bcl-2 family members are coordinately regulated by the JNK pathway and require Bax to induce apoptosis in neurons. J Biol Chem 276:37754-37760.

Hershko T, Ginsberg D (2004) Up-regulation of Bcl-2 homology 3 (BH3)only proteins by E2F1 mediates apoptosis. J Biol Chem 279:8627-8634.

Hsu LJ, Sagara Y, Arroyo A, Rockenstein E, Sisk A, Mallory M, Wong J, Takenouchi T, Hashimoto M, Masliah E (2000) alpha-synuclein promotes mitochondrial deficit and oxidative stress. Am J Pathol 157:401-410.

Hsu YT, Youle RJ (1998) Bax in murine thymus is a soluble monomeric protein that displays differential detergent-induced conformations. J Biol Chem 273:10777-10783.

Hutcheon B, Morley P, Poulter MO (2000) Developmental change in GABAA receptor desensitization kinetics and its role in synapse function in rat cortical neurons. J Physiol $522 \mathrm{Pt} \mathrm{1:3-17.}$

Jenner P (1998) Oxidative mechanisms in nigral cell death in Parkinson's disease. Mov Disord 13 [Suppl 1]:24-34.

Johnson MD, Kinoshita Y, Xiang H, Ghatan S, Morrison RS (1999) Contribution of p53-dependent caspase activation to neuronal cell death declines with neuronal maturation. J Neurosci 19:2996-3006.

Kim H, Rafiuddin-Shah M, Tu HC, Jeffers JR, Zambetti GP, Hsieh JJ, Cheng EH (2006) Hierarchical regulation of mitochondrion-dependent apoptosis by BCL-2 subfamilies. Nat Cell Biol 8:1348-1358.

Kiryu-Seo S, Hirayama T, Kato R, Kiyama H (2005) Noxa is a critical mediator of p53-dependent motor neuron death after nerve injury in adult mouse. J Neurosci 25:1442-1447.

Kluck RM, Bossy-Wetzel E, Green DR, Newmeyer DD (1997) The release of cytochrome $\mathrm{c}$ from mitochondria: a primary site for $\mathrm{Bcl}-2$ regulation of apoptosis. Science 275:1132-1136.

Kuwana T, Bouchier-Hayes L, Chipuk JE, Bonzon C, Sullivan BA, Green DR, Newmeyer DD (2005) BH3 domains of BH3-only proteins differentially regulate Bax-mediated mitochondrial membrane permeabilization both directly and indirectly. Mol Cell 17:525-535.

Le DA, Wu Y, Huang Z, Matsushita K, Plesnila N, Augustinack JC, Hyman BT, Yuan J, Kuida K, Flavell RA, Moskowitz MA (2002) Caspase activation and neuroprotection in caspase-3- deficient mice after in vivo cerebral ischemia and in vitro oxygen glucose deprivation. Proc Natl Acad Sci USA 99:15188-15193.

Letai (2002) A Distinct BH3 domains either sensitize or activate mitochondrial apoptosis, serving as prototype cancer therapeutics. Cancer Cell 2:183.

Ley R, Balmanno K, Hadfield K, Weston C, Cook SJ (2003) Activation of the ERK1/2 signaling pathway promotes phosphorylation and proteasomedependent degradation of the BH3-only protein, Bim. J Biol Chem 278:18811-18816.
Li H, Zhu H, Xu CJ, Yuan J (1998) Cleavage of BID by caspase 8 mediates the mitochondrial damage in the Fas pathway of apoptosis. Cell 94:491-501.

Li M (2000) Functional role of caspase- 1 and caspase-3 in an ALS transgenic mouse model. Science 288:335-339.

Li P (1997) Cytochrome c and dATP-dependent formation of Apaf-1/ caspase-9 complex initiates an apoptotic protease cascade. Cell 91:479-489.

Lyras L, Perry RH, Perry EK, Ince PG, Jenner A, Jenner P, Halliwell B (1998) Oxidative damage to proteins, lipids, and DNA in cortical brain regions from patients with dementia with Lewy bodies. J Neurochem 71:302-312.

Margaill I, Plotkine M, Lerouet D (2005) Antioxidant strategies in the treatment of stroke. Free Radic Biol Med 39:429-443.

Martin LJ (1999) Neuronal death in amyotrophic lateral sclerosis is apoptosis: possible contribution of a programmed cell death mechanism. J Neuropathol Exp Neurol 58:459-471.

Melino G, Bernassola F, Ranalli M, Yee K, Zong WX, Corazzari M, Knight RA, Green DR, Thompson C, Vousden KH (2004) p73 Induces apoptosis via PUMA transactivation and Bax mitochondrial translocation. J Biol Chem 279:8076-8083.

Miller TM, Moulder KL, Knudson CM, Creedon DJ, Deshmukh M, Korsmeyer SJ, Johnson Jr EM (1997) Bax deletion further orders the cell death pathway in cerebellar granule cells and suggests a caspaseindependent pathway to cell death. J Cell Biol 139:205-217.

Moreau C, Cartron PF, Hunt A, Meflah K, Green DR, Evan G, Vallette FM, Juin P (2003) Minimal BH3 peptides promote cell death by antagonizing anti-apoptotic proteins. J Biol Chem 278:19426-19435.

Neame SJ, Rubin LL, Philpott KL (1998) Blocking cytochrome c activity within intact neurons inhibits apoptosis. J Cell Biol 142:1583-1593.

Plesnila N, Zinkel S, Le DA, min-Hanjani S, Wu Y, Qiu J, Chiarugi A, Thomas SS, Kohane DS, Korsmeyer SJ, Moskowitz MA (2001) BID mediates neuronal cell death after oxygen/glucose deprivation and focal cerebral ischemia. Proc Natl Acad Sci USA 98:15318-15323.

Przedborski S, Ischiropoulos H (2005) Reactive oxygen and nitrogen species: weapons of neuronal destruction in models of Parkinson's disease. Antioxid Redox Signal 7:685-693.

Putcha GV, Moulder KL, Golden JP, Bouillet P, Adams JA, Strasser A, Johnson EM (2001) Induction of BIM, a proapoptotic BH3-only BCL-2 family member, is critical for neuronal apoptosis. Neuron 29:615-628.

Putcha GV, Le S, Frank S, Besirli CG, Clark K, Chu B, Alix S, Youle RJ, LaMarche A, Maroney AC, Johnson Jr EM (2003) JNK-mediated BIM phosphorylation potentiates BAX-dependent apoptosis. Neuron 38:899-914.

Puthalakath H, Strasser A (2002) Keeping killers on a tight leash: transcriptional and post-translational control of the pro-apoptotic activity of $\mathrm{BH} 3$ only proteins. Cell Death Differ 9:505-512.

Reimertz C, Kogel D, Rami A, Chittenden T, Prehn JH (2003) Gene expression during ER stress-induced apoptosis in neurons: induction of the $\mathrm{BH} 3$-only protein Bbc3/PUMA and activation of the mitochondrial apoptosis pathway. J Cell Biol 162:587-597.

Richardson JR, Caudle WM, Guillot TS, Watson JL, Nakamaru-Ogiso E, Seo BB, Sherer TB, Greenamyre JT, Yagi T, Matsuno-Yagi A, Miller GW (2007) Obligatory role for complex I inhibition in the dopaminergic neurotoxicity of 1-methyl-4-phenyl-1,2,3,6-tetrahydropyridine (MPTP). Toxicol Sci 95:196-204.

Simpson EP, Yen AA, Appel SH (2003) Oxidative stress: a common denominator in the pathogenesis of amyotrophic lateral sclerosis. Curr Opin Rheumatol 15:730-736.

Sugawara T, Chan PH (2003) Reactive oxygen radicals and pathogenesis of neuronal death after cerebral ischemia. Antioxid Redox Signal 5:597-607.

Tatton NA, Maclean-Fraser A, Tatton WG, Perl DP, Olanow CW (1998) A fluorescent double-labeling method to detect and confirm apoptotic nuclei in Parkinson's disease. Ann Neurol 44:S142-S148.

Tieu K, Ischiropoulos H, Przedborski S (2003) Nitric oxide and reactive oxygen species in Parkinson's disease. IUBMB Life 55:329-335.

Tsujimoto Y (2003) Cell death regulation by the Bcl-2 protein family in the mitochondria. J Cell Physiol 195:158-167.

Vila M, Przedborski S (2003) Targeting programmed cell death in neurodegenerative diseases. Nat Rev Neurosci 4:365-375.

Villunger A, Michalak EM, Coultas L, Mullauer F, Bock G, Ausserlechner MJ, Adams JM, Strasser A (2003) p53- and drug-induced apoptotic responses mediated by $\mathrm{BH} 3$-only proteins puma and noxa. Science 302:1036-1038.

Whitfield J, Neame SJ, Paquet L, Bernard O, Ham J (2001) Dominant- 
negative c-Jun promotes neuronal survival by reducing BIM expression and inhibiting mitochondrial cytochrome $c$ release. Neuron 29:629-643.

Willis SN, Fletcher JI, Kaufmann T, van Delft MF, Chen L, Czabotar PE, Ierino H, Lee EF, Fairlie WD, Bouillet P, Strasser A, Kluck RM, Adams JM, Huang DC (2007) Apoptosis initiated when BH3 ligands engage multiple Bcl-2 homologs, not Bax or Bak. Science 315:856-859.

Wolter KG, Hsu YT, Smith CL, Nechushtan A, Xi XG, Youle RJ (1997) Movement of Bax from the cytosol to mitochondria during apoptosis. J Cell Biol 139:1281-1292.

Wood KA, Youle RJ (1995) The role of free radicals and p53 in neuron apoptosis in vivo. J Neurosci 15:5851-5857.

Wyttenbach A, Tolkovsky AM (2006) The BH3-only protein Puma is both necessary and sufficient for neuronal apoptosis induced by DNA damage in sympathetic neurons. J Neurochem 96:1213-1226.

Xiang H, Hochman DW, Saya H, Fujiwara T, Schwartzkroin PA, Morrison RS
(1996) Evidence for p53-mediated modulation of neuronal viability. J Neurosci 16:6753-6765.

Yoshida H, Kong YY, Yoshida R, Elia AJ, Hakem A, Hakem R, Penninger JM, Mak TW (1998) Apafl is required for mitochondrial pathways of apoptosis and brain development. Cell 94:739-750.

You H, Pellegrini M, Tsuchihara K, Yamamoto K, Hacker G, Erlacher M, Villunger A, Mak TW (2006) FOXO3a-dependent regulation of Puma in response to cytokine/growth factor withdrawal. J Exp Med 203:1657-1663.

Zhang J, Graham DG, Montine TJ, Ho YS (2000) Enhanced N-methyl-4phenyl-1,2,3,6-tetrahydropyridine toxicity in mice deficient in CuZnsuperoxide dismutase or glutathione peroxidase. J Neuropathol Exp Neurol 59:53-61.

Zong WX, Lindsten T, Ross AJ, MacGregor GR, Thompson CB (2001) $\mathrm{BH} 3$-only proteins that bind pro-survival Bcl-2 family members fail to induce apoptosis in the absence of Bax and Bak. Genes Dev 15:1481-1486. 